\title{
Development of the Composition and Manufacturing Technology of a New Combined Drug: Lavaflam
}

\author{
Yeni Kombine Bir İlacın, Lavaflam, Bileşimi ve Üretim Teknolojisinin \\ Geliştirilmesi
}

\author{
(D) Tanya IVKO ${ }^{*}$, (1) Milena ASLANIAN ${ }^{3}$, (D) Larisa BOBRYTSKA ${ }^{3}$, (D) Natalia POPOVA ${ }^{3}$, (D) Olena NAZAROVA², (D) Natalia BEREZNYAKOVA ${ }^{3}$, \\ (D) Tamara GERMANYUK'1
}

'National Pirogov Memorial Medical University, Vinnytsya, Ukraine

2State Enterprise State Scientific Center for Drugs and Medical Products, Kharkov, Ukraine

${ }^{3}$ National University of Pharmacy, Kharkov, Ukraine

\begin{abstract}
Objectives: Treatment of diseaes of the biliary system is one of the urgent problems of modern medicine.

Materials and Methods: An original pharmaceutical drug "Lavaflam" in the form of combined tablets, which includes a composition of herbal components flamin $(0.05 \mathrm{~g})$ and lavender oil $(0.02 \mathrm{~g})$, was proposed for the complex treatment of diseases of the biliary system. Flamin is phytomedicine from the immortelle flowers [Helichrysum arenarium (L.) Moench, Asteraceae], which contains a complex of active substances from the flavonoids group (salipurposide, isosalipurposide, kaempferol, luteolin). It is applied as a choleretic and an anti-inflammatory agent in cholecystitis, cholangitis, and biliary dyskinesia. Tablets were prepared by pressing for separate granulation technology.

Results: The lavender oil granulate was prepared using the solid phase method, and $\beta$-cyclodextrin was used as an excipient substance. The flamin granulate was prepared by mixing with the spherical-shaped filler mannitol PARTECK M 200. On the basis of previous studies, the excipients of the designed composition tablet "Lavaflam" were $\beta$-cyclodextrin $(0.27 \mathrm{~g})$, mannitol PARTECK M 200 (0.20 g), croscarmellose sodium (0.03 $\mathrm{g}$ ), potato starch $(0.022 \mathrm{~g}), \mathrm{PEG} 6000(0.002 \mathrm{~g})$, and magnesium stearate $(0.006 \mathrm{~g})$. The assay of the main components of lavender oil with the references linalol and linalyl acetate was performed using gas chromatography. The assay of the total flavonoids of flamin was performed using spectrophotometry with isosalipurposide as the reference.

Conclusion: The new phytomedicine tablets "Lavaflam" meet European Pharmacopoeia requirements on the following parameters: appearance, geometric size, average weight, disintegration, friability, resistance of tablets to crushing, and quantification.
\end{abstract}

Key words: Lavender oil, flamin, tablets Lavaflam

öz

Amaç: Biliyer sistem hastalıklarının tedavisi, modern tıbbın acil problemlerinden biridir.

Gereç ve Yöntemler: Biliyer sistem hastalıklarının karmaşık tedavisi için, bitkisel bileşenler flamin (0.05 g) ve lavanta yağından ( $0.02 \mathrm{~g}$ ) oluşan bir bileşimi içeren kombine tablet formundaki formdaki orijinal farmasötik ilaç "Lavaflam" önerilmiştir. Flamin, flavonoidler grubundan (salipurposid, isosalipurposide, kaempferol, luteolin) aktif maddelerden oluşan bir kompleks içeren, ölmez çiçeklerden [Helichrysum arenarium (L.) Moench, Asteraceae] elde edilen bitkisel kaynaklı ilaçtır. Kolesistit, kolanjit ve biliyer diskinezide koloretik ve anti-inflamatuvar ajan olarak uygulanır. Tabletler, ayrı granülasyon teknolojisi için preslenerek hazırlandı.

Bulgular: Lavanta yağı granülesi katı faz metodu kullanılarak hazırlandı ve $\beta$-siklodekstrin yardımcı madde olarak kullanıldı. Flamin granülesi küresel şekilli dolgu maddesi mannitol PARTECK M 200 ile karıştırılarak hazırlandı. Önceki çalışmalara dayanarak, tasarlanan "Lavaflam" tablet bileşiminin eksipiyanları, $\beta$-siklodekstrin ( $0.27 \mathrm{~g}$ ), mannitol PARTECK M 200 (0.20 g), kroskarmeloz sodyum (0.03 g), patates nişastası (0.022 g), PEG 6000 $(0.002 \mathrm{~g})$ ve magnezyum stearat $(0.006 \mathrm{~g})$ idi. Lavanta yağının ana bileșenlerinin analizi linalol ve linalil asetat referansları ile, gaz kromatografisi kullanılarak gerçekleştirildi. Flaminin toplam flavonoidlerinin analizi, referans olarak isosalipurposid ile spektrofotometri kullanılarak gerçekleştirildi. Sonuç: Yeni bitkisel kaynaklı tabletler "Lavaflam", Avrupa Farmakopesi gereksinimlerini aşağıdaki parametrelerle karşılamaktadır: görünüm, geometrik boyut, ortalama ağırlık, dağılma, ufalanabilirlik, tabletlerin kırılmaya karşı direnci ve miktar tayini.

Anahtar kelimeler: Lavanta yağı, flamin, Lavaflam tabletleri

*Correspondence: E-mail: ivkot1981@gmail.com, Phone: +380982640560 ORCID-ID: orcid.org/0000-0003-2873-1473

Received: 21.07.2017, Accepted: 07.09.2017

๑Turk J Pharm Sci, Published by Galenos Publishing House. 


\section{INTRODUCTION}

Treatment of diseases of the biliary system is one of the urgent problems of modern medicine. ${ }^{1-4}$ Diseases of the liver and biliary tract are very common, occurring in $10-20 \%$ of the population of developed countries. According to statistics, in Ukraine, the number of such patients is constantly increasing. ${ }^{5}$ Currently, combined drugs are the leading pharmacotherapeutic agents, including those for the treatment of diseases of the biliary system, which require complex treatment. The choice of drug combination allows to expand the range of action of the drug and the complex influence on the disease, enhance the activity of every ingredient, as well improve tolerability and reduce adverse effects. ${ }^{6,7}$

Modern herbal medicines are widely used in the complex treatment of various diseases, including in the biliary system. They are characterized by high efficiency, low toxicity, and the possibility of long-term use without the risk of adverse effects ${ }^{5,8}$ Complex treatment of biliary disease is the reason for the creation of drugs of herbal origin, because herbal remedies usually possess many pharmacologic effects and have low levels of adverse effects. Nowadays, immortelle-containing drugs are widely used, which are well-known in the Ukraine and some countries of the former Soviet Union. One of them is flamin, which has choleretic action, but also has established hepatoprotective, antimicrobial, and antiviral properties. This is why it is possible to broaden the variety of action by combining flamin with lavender oil. Adding lavender oil to flamin increases the peristalsis of biliary tract and improves the detoxication function of the liver. ${ }^{8-11}$ Pre-clinical in vivo research was conducted under the direction of Prof. Drogovoz in the department of pharmacology of National University of Pharmacy, Kharkov, Ukraine, and the indicated effects were confirmed. ${ }^{9}$ The aim of the research was to develop an original drug composition and technology in the form of tablets that included a combination of herbal substances, flamin and lavender oil.

\section{MATERIALS AND METHODS}

The objects of research were medicinal substances of herbal origin flamin $(0.05 \mathrm{~g})$, lavender oil $(0.02 \mathrm{~g})$, as well as excipient substances and tablets named "Lavaflam". Lavaflam is new drug in the form of tablets, consisting of flamin, lavender oil, and excipients: $\beta$-cyclodextrin $(0.27 \mathrm{~g})$, mannitol PARTECK M $200(0.20 \mathrm{~g})$, croscarmellose sodium $(0.03 \mathrm{~g})$, potato starch $(0.022 \mathrm{~g})$, polyethylene glycol (PEG) $6000(0.002 \mathrm{~g})$, magnesium stearate $(0.006 \mathrm{~g})$. To achieve this goal, it was necessary to analyze the biologically active compounds of flamin and lavender oil, their stability in tablets, as well to choose excipients and to perform pharmacotechnological analysis of them. Flamin (Pharmaceutical company "Zdorovye", Kharkov, Ukraine) is a yellow or brownish-yellow powder with a weak specific smell, easily soluble in $96 \%$ alcohol, and practically insoluble in water and chloroform. ${ }^{2}$ Flamin is obtained from the immortelle flowers [Helichrysum arenarium (L.) Moench, Asteraceae] by extraction of $50 \%$ ethanol followed by purification. ${ }^{13,14}$ It contains flavonoid glycosides and aglycones (salipurposide, isosalipurposide, kaempferol, luteolin, naringenin, apigenin and others), essential oils, organic acids, polysaccharides, and other biologically active substances of different groups. ${ }^{13-15}$ The antimicrobial and antiviral activity of flamin and other drugs from immortelle flowers has been established. ${ }^{6,10,13,14,16-21}$ Analysis of total flavonoids were conducted using spectrophotometry with the reference isosalipurposide-standard (specific absorption index). ${ }^{7,13,14,16}$

\section{Assay of total flavonoids in flamin}

The test solution. About $0.60 \mathrm{~g}$ (accurately weighed) powdered tablets was placed in a $100 \mathrm{~mL}$ volumetric flask, $70 \mathrm{~mL}$ of $96 \%$ ethanol was added, and allowed to stand in an ultrasonic bath for 5 minutes, diluted to $100 \mathrm{~mL}$ with the same solvents, stirred, and filtered through a paper filter "blue ribbon", and the first $15 \mathrm{~mL}$ of filtrate was discarded. Two millilitres of the resulting solution was diluted with $96 \%$ alcohol to a volume of $50.0 \mathrm{~mL}$ and stirred. The absorbance of the test solution was measured using a spectrophotometer (ultraviolet visible HP 8453, Hewlett Packard, USA) at a wavelength $315 \mathrm{~nm}$ in a cuvette with $10 \mathrm{~mm}$ thickness, using $96 \%$ alcohol as a compensation solution.

The total flavonoid expressed as isosalipurposide $\left(X_{1}, \%\right)$ in a single tablet was calculated using Equation 1:

$X_{1}=\frac{A \times 100 \times 50 \times b}{E_{1 \mathrm{~mm}}^{1 \%} \times m \times 2 \times 100}=\frac{A \times 25 \times b}{E_{1 \mathrm{sm}}^{1 \%} \times m} \quad$ (Equation 1)

Where: $\mathrm{A}$ - the absorbance of the test solution at $\lambda=315 \mathrm{~nm}$; $E_{1 \mathrm{sm}}^{1 \%}$ isosalipurposide's specific absorption ( $96 \%$ alcohol) at $\lambda=$ $315 \mathrm{~nm}$ is 260;

$\mathrm{m}$ : mass of the drug sample, in grams;

$b$ : the average weight of the tablets, in milligrams.

Amount of total flavonoids expressed as isosalipurposide should be 31.0-39.0 $\mathrm{mg}$ of the nominal content.

Lavender oil was obtained from the flower of Lavandula angustifolia Mill, Lamiaceae. Lavender oil (Pharmaceutical company "Zdorovye", Kharkov, Ukraine) is a transparent, colorless or pale yellow liquid with a specific fragrance. ${ }^{22,23}$ The analysis of lavender oil was conducted according to the requirements of the European Pharmacopoeia and Ukrainian State Pharmacopeia, which regulate the content of the following main components in lavender oil: limonene: less than 1.0\%; 3-octanone: $0.1-2.5 \%$; camphor: less than $1.2 \%$; linalool: 20.0-45.0\%; linalyl acetate: 25.0-46.0\%; terpinene-4-ol: 0.1$6.0 \%$; lavandulyl acetate: more than $0.2 \%$; lavandulol: more than $0.1 \%$; and $\alpha$-terpineol: less than $2.0 \%$. From the above normalization, the main components of lavender oil are linalol and linalyl acetate. Analysis of these terpenoids was performed using gas chromatography (GC) with internal normalization. A method for the assay of lavender oil in a combined pharmaceutical preparation "Lavaflam" were developed using a gas chromatograph Agilent 7890 (USA) with a flame ionization 
detector. Lavender oil was used $(1 \mathrm{mg} / \mathrm{mL})$ as the standard sample solution. The calculation was performed for the amount of linalool and linalyl acetate (11).

\section{Methods of analysis of lavender oil in "Lavaflam" tablets}

The test solution. About $0.75 \mathrm{~g}$ (accurately weighed) of 20 powdered tablets was placed in a $25 \mathrm{~mL}$ volumetric flask, $15 \mathrm{~mL}$ of methanol was added, allowed to stand in an ultrasonic bath for 10 minutes, and the volume was diluted with the same solvent and thoroughly mixed. The resulting suspension was filtered through a paper filter "blue tape", discarding the first $5 \mathrm{~mL}$ of filtrate. The solution used was freshly prepared. Reference solution. About $0.5 \mathrm{~g}$ (accurately weighed) of lavender oil was placed in 50-mL volumetric flask, diluted with $50 \mathrm{~mL}$ methanol and thoroughly mixed. Five millilitres of this solution was placed in a $50 \mathrm{~mL}$ volumetric flask, diluted with methanol, and thoroughly mixed. The solution used was freshly prepared. One microliter of test solution and reference solution were chromatographed using a GC with a flame ionization detector.

Lavender oil content $\left(X_{2}\right)$ in grams per tablet was calculated using Equation 2:

$$
X_{2}=\frac{\sum S_{i} \times m_{o} \times 5 \times 25 \times \mathrm{b}}{\sum S_{o} \times m \times 50 \times 50}=\frac{\sum S_{i} \times m_{o} \times \mathrm{b}}{\sum S_{o} \times m \times 20},(\text { Equation 2) }
$$

where: $\Sigma S_{i}$-average value of the sum of areas of peaks of linalol and linalyl acetate, calculated from the chromatogram of the test solution;

$\Sigma S_{0}$-average sum of the areas of peaks of linalol and linalyl acetate, calculated from the chromatogram of the reference solution;

b-the average tablet weight calculated for 20 tablets ( $g$ );

$\mathrm{m}_{\mathrm{o}}$ : mass of lavender oil $(\mathrm{g})$;

$\mathrm{m}$ : mass of sample preparation (g).

Normalization lavender oil content is set within $90 \%-110 \%$ of the nominal content.

Pharmaco-technological studies have been carried out for development of the composition of excipients. ${ }^{24}$ The bulk density, tap density, flowability, the angle of repose, compressibility, friability, and resistance of the tablets to crushing were determined on the "Pharma test" devices (Germany), and the disintegration on apparatus from "Erweka" (Germany). Flowability was evaluated using the Carr index and Hausner's index. ${ }^{25,26}$

Pharmacologic and technological properties of powders and granulates

\section{Determination of the bulk density}

The bulk density is the weight of a unit volume of a powder loosely placed into a measuring cylinder. It depends on the density of a substance, the particle size and shape, and its compatibility.

One hundred grams of the substance being examined is introduced to a dry cylinder without compacting.
The bulk density is calculated in g per $\mathrm{mL}$ using the formula $\mathrm{m} / \mathrm{V}_{0}$.

Determination of the density

The cylinder is fixed in its holder. Ten, 500, and 1250 taps are performed and the corresponding volumes $\mathrm{V}_{10}, \mathrm{~V}_{500}$ and $\mathrm{V}_{1250}$ are read to the nearest milliliter. The tap density is calculated in $\mathrm{g}$ per $\mathrm{mL}$ using the formula $\mathrm{m} / V_{\mathrm{f}}$ in which $V_{\mathrm{f}}$ is the final tapped volume.

\section{Determination of flowability}

Flowability characterizes the ability of a material to pour out from the container (a feeding funnel) under its own weight. Flowability was determined by outlet velocity of the fixed quantity of the material $(100 \mathrm{~g})$ pouring out from a metal funnel with strictly geometric parameters and by the angle of repose. The flowability is expressed in seconds, related to $100 \mathrm{~g}$ of the sample.

\section{Determination of angle of repose}

The indirect characteristic of flowability is the angle of repose. Powdery materials form a conical hill on a horizontal plane after being poured out from a funnel. The angle between the incline and the base of this hill is called the angle of repose, and is expressed in degrees. It was determined with a goniometer or measured in another way. The angle of repose changes over a wide range from $25-35^{\circ}$ for well flowing materials and up to $60-70^{\circ}$ for poorly flowing ones.

\section{Determination of Carr index and Hausner's index}

The Carr index and Hausner index are used to describe the flowability of a powder. According to Carr, an excellent flowability is between a Carr index of $5 \%$ to $15 \%$; a Carr index of above $25 \%$ normally shows poor flowability.

Carr Index $=\frac{(\text { ptap }- \text { pbulk })}{\text { ptap }} \quad \times 100 \%$

With a Hausner index of 1.0 to 1.1, a powder is considered as free flowing, greater than 1.1 to 1.25 , a powder is classified as medium flowing, if greater than 1.25 to 1.4 , a powder is classified as difficult to flow, and higher than 1.4 is considered to be very difficult to flow.

Haunser Index $=\frac{\text { ptap }}{\text { pbulk }}$

\section{Determination of compressibility}

To determine compressibility, a sample of the powder was compressed $(0.3-0.5 \mathrm{~g}$ ) within a matrix of 9 or $11 \mathrm{~mm}$ in diameter, respectively, on a hydraulic press at pressure 120 $\mathrm{MPa}$. Compressibility can also be also evaluated by the hardness of the obtained tablet.

\section{Used excipients}

To obtain tablets, lavender oil was converted to the solid state. Lavender oil granulate was prepared using the solid phase method, $\beta$-cyclodextrin was used as an excipient substance. Cyclodextrins are used in pharmaceutical technology in order to 
build complex systems with a variety of active pharmaceutical ingredients, thereby largely improving their bioavailability and solubility, and increase chemical and physical stability. Cyclodextrin complexes are used to mask the unpleasant taste of active substances and converting liquid substances into solids. ${ }^{27-30}$ Granulak 70 ("Meggle Excipients", Germany) is a crystalline form of lactose, it consists of fine particles with sharp edges and has cohesion properties that can be useful in the process of granulation. The following substances were used as fillers: tabletoza 70, microcrystalline cellulose (MCC) 102, di-calcium phosphate (for direct compression), mannitol PARTECK M 200 (for direct compression), and saccharose compressible grade B. Disintegrants were used to improve the disintegration..$^{30,31}$ According to the literature ${ }^{30}$, as a disintegrants, it is better to use starch in combination with other substances with disintegrating action. In the powdering step, various combinations of the potato starch with the following excipients were used as the disintegrant: sodium croscarmellose, sodium starch glycolate and crospovidone. Lubricants were used to prevent adhesion, improve flowability and plasticity of the granulate for tableting. For this purpose, magnesium stearate in combination with PEG 6000 was used in the dusting granulate stage.

\section{Preparation of granulate}

\section{Preparation of granulate $A$}

$\beta$-cyclodextrin was mixed with water $(30-40 \%)$ for $3-5$ minutes in a laboratory mixer until a paste was formed. Lavender oil was added to the resulting paste with stirring for 5-10 min. The resulting mass was dried in a tray dryer at room temperature for 48 hours, stirring periodically. After drying, the mass was granulated through a sieve (holes diameter $1.0 \mathrm{~mm}$ ) to obtain a homogeneous granulate (granulate $A$ ).

\section{Preparation of granulate $B$}

Considering the obtained results of flowability values, it is advisable to use $0.2 \mathrm{~g}$ PARTECK M 200 mannitol filler for powder flamin. Due to its the spherical shape, mannitol PARTECK M 200 is evenly distributed between the particles of flamin powder, while improving the flowability and uniformity of the resulting granulate mass. When mixed, flamin with mannitol PARTECK M 200 was then granulated through a sieve (holes diameter 1.0 $\mathrm{mm}$ ) obtaining granules $\mathrm{B}$.

\section{Quality control tests of tablets}

Determination of tablet friability

A drum type friabilator was used to determine abrasion of tablets. Tablets were dedusted and weighed with an accuracy of $0.001 \mathrm{~g}$, then placed in a drum, covered with a lid, and the device was allowed to run for 4 minutes, with 100 revolutions. The tablets were dedusted, and if they had no chips and cracks their mass was determined with an accuracy of $0.001 \mathrm{~g}$. The abrasion of the tablets in percentages was calculated using the following formula:

$\mathrm{U}=\frac{\mathrm{m}_{1}-\mathrm{m}_{2}}{\mathrm{~m}_{1}} \times 100 \%$
Where,

$m_{1}$ : mass of tablet before friability,

$\mathrm{m}_{2}$ : mass of tablet after friability.

The loss in mass of the tested tablets should be not more than $1 \%$ of the total mass of the tested tablets.

\section{Determination resistance of tablets to crushing}

This test is intended to determine, under defined conditions, the resistance to crushing of tablets measured by the force needed to disrupt them by crushing. The apparatus consists of 2 jaws facing each other, one moves towards the other. The tablet was placed between the jaws taking into account, where applicable, the shape, the break-mark and the inscription; for each measurement, the tablet was oriented in the same way with respect to the direction of application of the force. Measurements of 10 tablets were performed.

The load that caused the destruction of the tablets is a measure of strength. The obtained strength value is measured in Newtons.

\section{Determination of tablets disintegration}

This test is used to determine whether tablets disintegrate within the prescribed time when placed in a liquid (water). One dosage unit is placed in each of the 6 tubes of the basket. Operate the apparatus using the specified medium adjusted at $37 \pm 2^{\circ} \mathrm{C}$ as the immersion liquid. At the end of the specified time, the basket is lifted from the liquid and the dosage units are observed: all of the dosage units should have disintegrated completely. A tablet should be broken up within not more than $15 \mathrm{~min}$.

\section{Determination of the average weight of tablets}

Twenty tablets are weighed separately with an accuracy of $0.001 \mathrm{~g}$ and their average mass is calculated. The deviation of the average mass of tablets from the mass specified in the "composition" section should not exceed $\pm 5 \%$. This work is technological and did not require approval from the ethics committee.

\section{Statistical analysis}

All analyses were carried out in triplicate. The results of research were analyzed using Excel 2007 and STATISTICA 6.0 using the average of all samples and are reported as mean \pm standard deviation.

\section{RESULTS AND DISCUSSION}

According to the literature, it is known ${ }^{30}$ that the concentration of $\beta$-cyclodextrin affects the stability of essential oils during storage. To determine the optimal concentration of $\beta$-cyclodextrin granules with lavender oil, samples were prepared with different amounts of $\beta$-cyclodextrin: $0.15 \mathrm{~g}, 0.20$ g, $0.25 \mathrm{~g}, 0.27 \mathrm{~g}$, and $0.30 \mathrm{~g}$. Stability during storage for 5 weeks was determined by the analysis of the concentration of lavender oil. The main components of lavender oil are linalool and linalyl acetate. Analysis of the lavender oil's components was conducted using GC. Lavender oil and granulak 70 was 


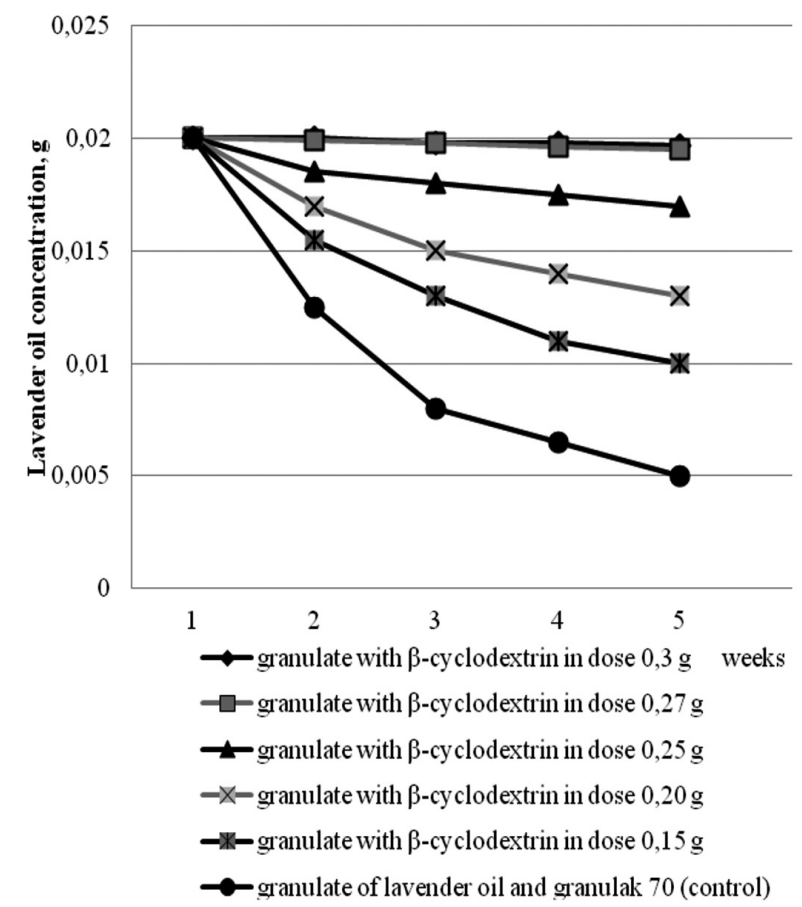

Figure 1. Effect of $\beta$-cyclodextrin concentration on the stability lavender oil during storage

\section{Table 1. Pharmaco-technological properties of flamin}

\begin{tabular}{lll}
$\begin{array}{l}\text { Pharmaco-technological } \\
\text { properties }\end{array}$ & Units & Result \\
\hline Bulk density & $\mathrm{g} / \mathrm{mL}$ & $0.35 \pm 0.01$ \\
\hline Tap density & $\mathrm{g} / \mathrm{mL}$ & $0.62 \pm 0.01$ \\
\hline Flowability & $\mathrm{sec} / 100 \mathrm{~g}$ of sample & $107.10 \pm 1.30$ \\
\hline Angle of repose & degree & $65 \pm 1.0$ \\
\hline Compressibility & $\mathrm{N}$ & $75.0 \pm 1.0$ \\
\hline Carr index & $\%$ & $43.0 \pm 1.0$ \\
\hline Hausner index & - & $1.77 \pm 0.01$ \\
\hline
\end{tabular}

used as a control (without $\beta$-cyclodextrin) to compare the stability of granules. The effect of $\beta$-cyclodextrin concentration on lavender oil stability during storage is shown in Figure 1. $\beta$-cyclodextrin has a stabilizing effect on lavender oil during storage. The granulate, which contains $\beta$-cyclodextrin in a dose $0.30 \mathrm{~g}$ and $0.27 \mathrm{~g}$ of lavender oil, was not changed and a constant value was $0.02 \mathrm{~g}$ for 5 weeks. The granulate with granulak 70 (without $\beta$-cyclodextrin), lavender oil concentration after 2 weeks' storage decreased almost 2 times. Thus on the basis of the research, we have chosen the concentration of $\beta$-cyclodextrin in a granulate with lavender oil, $0.27 \mathrm{~g}$, which allows to maintain stability during storage for 5 weeks. The results of the stability studies of the lavender oil granulate with $\beta$-cyclodextrin in an amount of $0.27 \mathrm{~g}$ at different temperatures $\left(20 \pm 5^{\circ} \mathrm{C}\right)$ and $\left(40 \pm 5^{\circ} \mathrm{C}\right)$ are shown in Figure 2. As a result of this study, it was found that lavender oil concentration is stable for 12 months at a temperature of $20 \pm 5^{\circ} \mathrm{C}$, and the lavender oil concentration in the granulate gradually decreases at a temperature of $40 \pm 5^{\circ} \mathrm{C}$ after 3 months storage. These results allow us to determine the temperature at which lavender oil will remain stable during storage. It has been found that the lavender oil is almost completely evaporated after 12 days in research of the stability of a powdered mixture of lavender oil and $\beta$-cyclodextrin (obtained without the hydration process) at $20 \pm 5^{\circ} \mathrm{C}$. Consequently the complex is formed only in the presence of water. The obtained results confirm the formation of the complex due to the process of hydration and optimal concentration of $\beta$-cyclodextrin. $\beta$-cyclodextrin molecules have the form of a truncated cone that is hollow inside. In the presence of water, the inner cavity gets hydrophobic properties because of glycoside molecules and it plays the role of a "master". This arrangement allows placing "guest molecules" of lavender oil inside the cavity, thus stabilizing it. Microscopic observations showed that there were no oil inclusions of free lavender oil in the samples-t confirms the formation of the complex. For the development of the composition of the excipients of tablets and a choice of rational technology, the next step of the research was to study the pharmaco-technological properties of flamin (Table 1). The results of technological properties of the substance flamin (Table 1) showed that it had low flowability.

Table 2. Pharmaco-technological properties of excipient

\begin{tabular}{|c|c|c|c|c|c|}
\hline Name of excipient & Solubility & $\begin{array}{l}\text { Bulk density, } \\
\mathrm{g} / \mathrm{mL}\end{array}$ & $\begin{array}{l}\text { Tap density, } \\
\mathrm{g} / \mathrm{mL}\end{array}$ & $\begin{array}{l}\text { Flowability } \\
\mathrm{sec} / 100 \mathrm{~g} \text { of } \\
\text { sample }\end{array}$ & $\begin{array}{l}\text { Index Karra. } \\
\%\end{array}$ \\
\hline Tabletosa 70. "Meggle excipients", Germany & $\begin{array}{l}\text { Slowly soluble in } \\
\text { water }\end{array}$ & $0.53 \pm 0.01$ & $0.64 \pm 0.01$ & $15.3 \pm 0.1$ & $17 \pm 1$ \\
\hline Microcrystalline cellulose 102. “Mingtai chemical”, Taiwan & $\begin{array}{l}\text { Practically } \\
\text { insoluble in water }\end{array}$ & $0.33 \pm 0.01$ & $0.45 \pm 0.01$ & $30 \pm 0.1$ & $26 \pm 1$ \\
\hline Di-calcium phosphate. "Budenheim”, Germany & Insoluble in water & $0.45 \pm 0.01$ & $0.71 \pm 0.01$ & $9.3 \pm 0.1$ & $21 \pm 1$ \\
\hline $\begin{array}{l}\text { Mannitol. PARTECK } \\
\text { M 200. “Merck”, Germany }\end{array}$ & Soluble in water & $0.43 \pm 0.01$ & $0.57 \pm 0.01$ & $27 \pm 0.1$ & $24 \pm 1$ \\
\hline $\begin{array}{l}\text { Saccharose compressible grade B. "Suedzucker", } \\
\text { Germany }\end{array}$ & Soluble in water & $0.65 \pm 0.01$ & $0.72 \pm 0.01$ & $2.8 \pm 0.1$ & $9.7 \pm 0.5$ \\
\hline
\end{tabular}


This was confirmed by the microfine and complex surface of the powder particles and the high value of the angle of repose. The difference in bulk density and tap density indicates that the powder has caking ability. The Hausner index and Carr index also showed poor flowability values. Compressibility is characterized by model tablet strength after depressurization. Polydisperse particles of flamin powder contribute to the strength of the tablets. The substance has a satisfactory value of flamin compressibility. The greater the compressibility of the powder, the higher strength tablets. Pharmaco-technological research of flamin powder showed that to improve the flowability and the production of tablets it is necessary to use a complex of corresponding excipients to obtain a granular mass. ${ }^{31}$ Granulated masses were prepared with fillers (Table 2). Flowability was determined for each granulated mass. The results are shown in Figure 3. The use of excipient substances contributes to the formation of a granular mass with the powder of flamin and improves flowability. As can be seen from Figure 3 , for each filler these values are different and depend on the pharmaco-technical properties of each material, which are described in Table 2. Relatively good results were obtained for the granular mass mannitol PARTECK M 200 (30 sec/100 g sample), just below the phosphate di-calcium (33 sec/100 $\mathrm{g}$ sample) and sucrose in the pressing variety (35 sec/100 g

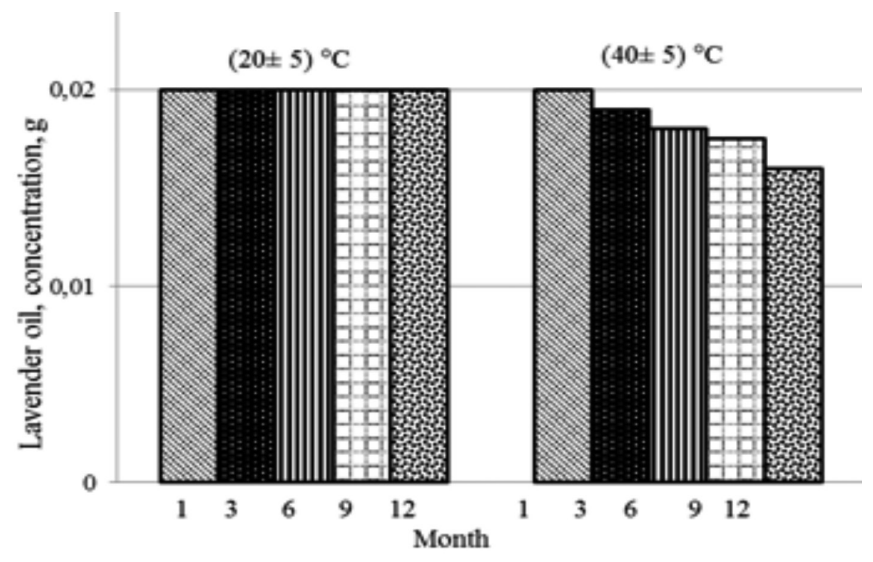

Figure 2. Study of stability lavender oil granulate with $\beta$-cyclodextrin at a temperature of $(20 \pm 5)^{\circ} \mathrm{C}$ and $(40 \pm 5)^{\circ} \mathrm{C}$

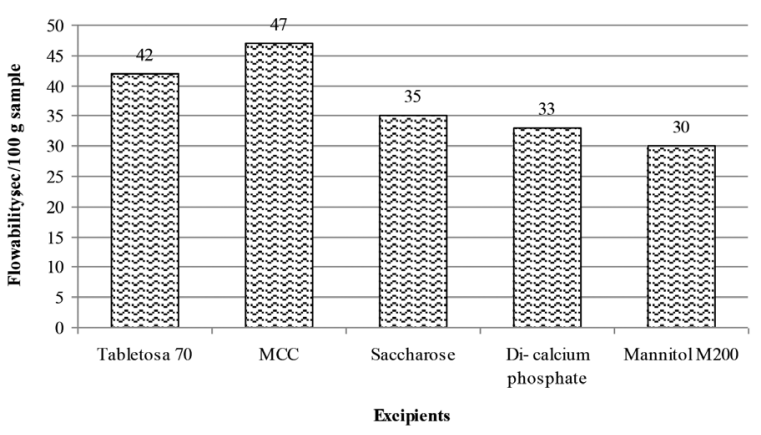

Figure 3. Comparative chart of flowability for various excipients MCC: Microcrystalline cellulose of sample). The flowability values were poor (unsatisfactory) for the granular mass with tabletoza 70 and MCC 102. The results of the effect of the amount of mannitol PARTECK $M$ 200, di-calcium phosphate, and saccharose pressing grade $B$ on flowability values are shown in Figure 4. Figure 4 shows that increased of amount of fillers improved flowability values, respectively. Adding mannitol PARTECK M 200 in an amount of $0.2 \mathrm{~g}$ to the flamin powder improved flowability to a value of 15 $\mathrm{sec} / 100 \mathrm{~g}$ sample, which is satisfactory. With further increases in amounts of mannitol PARTECK M 200 in the granulated mass, flowability values were practically unchanged. At the same concentration of fillers for flamin powder, flowability value with di-calcium phosphate was $20 \mathrm{sec} / 100 \mathrm{~g}$ of sample, and for saccharose compressible grade B-25 sec/100 g sample. Considering obtained results of flowability values, it is advisable to use mannitol PARTECK M 200 as a filler in an amount of 0.2 $\mathrm{g}$ for flamin powder.

The next step of the research was to combine and mix the granular mass. In a laboratory mixer, lavender oil granulate with $\beta$-cyclodextrin in an amount of $0.27 \mathrm{~g}$ (granulate $\mathrm{A}$ ) was combined with flamin granulate (granulate B), stirred, and then the resulting granular mass was screened through a sieve with a $1.0 \mathrm{~mm}$ hole diameter. An important indicator of the quality that affects the bioavailability of a drug is disintegration. The disintegration time for the different disintegrating agents was from 10 to 18 minutes depending on the nature of the disintegrants (Figure 5). The disintegration time for the starch, as opposed to a combination of substances, is set higher at 18 minutes. The combination of disintegrating agents has a complex mechanism of action on tablet disintegration due to the effect of wettability, capillarity, and swelling. The result of the experiment revealed that the sodium croscarmellose in combination with potato starch had a substantial effect on the disintegration of the tablet, and ultimately on the disintegration time, which was $10 \mathrm{~min}$. Due to the results of research, the excipients used in the composition of "Lavaflam" tablets were as follows: $\beta$-cyclodextrin $(0.27 \mathrm{~g})$, mannitol PARTECK

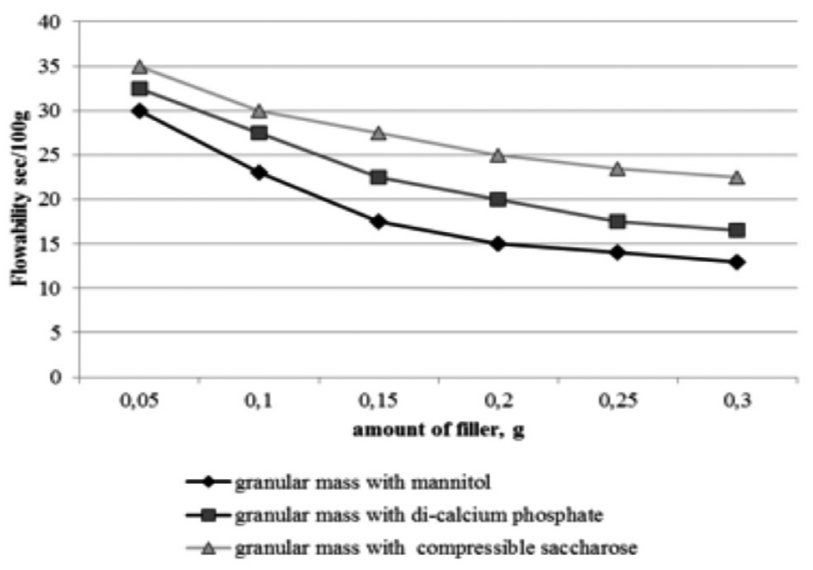

Figure 4. Effect of amount of fillers on flowability 
Table 3. Standardization of "Lavaflam" tablets

\begin{tabular}{|c|c|c|c|}
\hline Indicator & Results & Range measurement & Analysis \\
\hline 2. Size & $\begin{array}{l}\text { Diameter } \\
12.0 \pm 0.3 \mathrm{~mm} \text { height } \\
4.0 \pm 0.5 \mathrm{~mm}\end{array}$ & $\begin{array}{l}\text { Diameter } \\
12.0 \pm 0.3 \mathrm{~mm} \text { height } \\
4.0 \pm 0.5 \mathrm{~mm}\end{array}$ & Instrumental \\
\hline 4. Disintegration & $7 \pm 1 \mathrm{~min}$ & Not more than $15 \mathrm{~min}$ & Pharmaco-technological \\
\hline 5. Friability & $0.7 \pm 0.1 \%$ & Not more than $1 \%$ & Pharmaco-technological \\
\hline 6. Resistance of tablets to crushing & $110 \pm 10 \mathrm{H}$ & From $50 \mathrm{H}$ & Pharmaco-technological \\
\hline 7.2. Lavender oil & $20.2 \mathrm{mg}$ & From $18.0 \mathrm{mg}$ up to $22.0 \mathrm{mg}$ & Gas chromatography \\
\hline
\end{tabular}

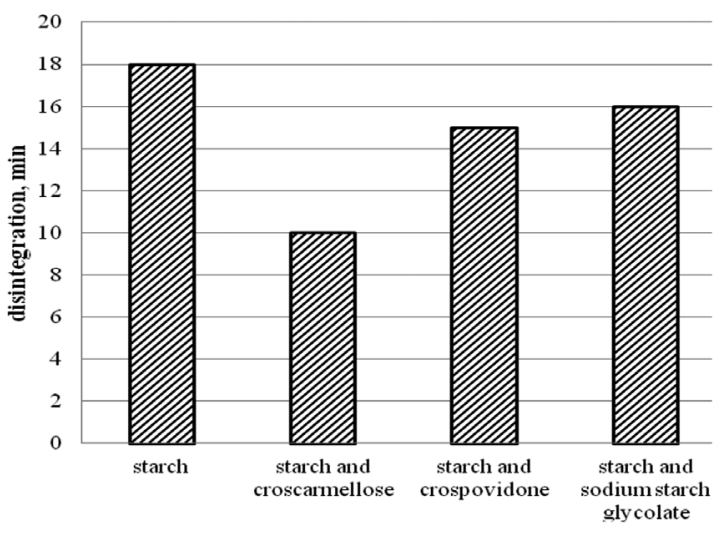

Figure 5. Effect of disintegrants on tablet disintegration

M $200(0.20 \mathrm{~g})$, croscarmellose sodium $(0.03 \mathrm{~g})$, potato starch $(0.022 \mathrm{~g}), \mathrm{PEG} 6000(0.002 \mathrm{~g})$, magnesium stearate $(0.006 \mathrm{~g})$. Tablets were prepared using compression with a separate granulation technique, which consisted of the following process steps:

- Preparation of raw materials,

- Preparation of lavender oil granulate with $\beta$-cyclodextrin (granulate A),

- Preparation of a granulate with a flamin (granulate B),

- The mixing, sifting and dusting of granulates $A$ and $B$,

- Tabletting and dedusting,

- Packing of tablets in blisters,

- Packaging blisters in packs,

- Packaging packs into group container.

Standardization of "Lavaflam" tablets was performed based on the following parameters: appearance, geometric size, average weight, disintegration, abrasion resistance, compressive strength, assay (the amount of flavonoids was calculated in recalculation in isosalipurposide, lavender oil - in linalool and linalool acetate). The results are shown in Table 3. The results of research indicated that "Lavaflam" tablets (Table 3) met the European and Ukrainian State Pharmacopoeia requirements (the Ukrainian Pharmacopoeia is harmonized with the European Pharmacopoeia). Specifications for the control of quality of "Lavaflam" tablets have been developed."116

\section{CONCLUSIONS}

The combination phytomedicine "Lavaflam" tablets meet European Pharmacopoeia requirements on the following parameters: appearance, geometric size, average weight, disintegration, friability, resistance of tablets to crushing, and quantification. Lavaflam is planned for manufacture under industrial conditions by the pharmaceutical company "Zdorovya". The introduction of the drug will modernize the current regimens for the treatment of liver and bile duct diseases.

\section{ACKNOWLEDGEMENTS}

Authors want to express their gratitude for the idea of "Lavaflam" tablets, continuous support to Prof., Doctor of science Litvinenko V.I. (Kharkov, Ukraine).

Conflict of Interest: No conflict of interest was declared by the authors.

\section{REFERENCES}

1. Liang TB, Liu Y, Bai XL, Yu J, Chen W. Sphincter of Oddi laxity: An important factor in hepatolithiasis. World J Gastroenterol. 2010;16:1014-1018.

2. Portincasa $P$, Wang $D Q$. Intestinal absorption, hepatic synthesis, and biliary secretion of cholesterol: where are we for cholesterol gallstone formation? Hepatology. 2012;55:1313-1316.

3. Wang DQ, Cohen DE, Carey MC. Biliary lipids and cholesterol gallstone disease. J Lipid Res. 2009;50(Suppl):406-411. 
4. Wang $\mathrm{DQ}$, Zhang L, Wang $\mathrm{HH}$. High cholesterol absorption efficiency and rapid biliary secretion of chylomicron remnant cholesterol enhance cholelithogenesis in gallstone-susceptible mice. Biochim Biophys Acta. 2005;1733:90-99.

5. Bobritskaya LA, Arakelyan MA, Popova NV. Marketing research of the market of drugs with the choleretic action. News of pharmacy. 2014;2:63-67.

6. Bobritskaya LA, Ruban HA, Osolodchenko TP, Shcherbak ON, Dmitrievskiy DI. Antibacterial properties of pharmaceutical compositions with ornidazole and flamini. Annals of Mechnikov Institute. 2013;1:27-31.

7. Bobritskaya LA, Popova NV, Ruban EA. Assessment of the quality of capsules with flamin and ornidazole. Pharmacy. 2013;5:20-22.

8. Drogovoz SM, Shtrygol SY, Shchekina EG. Pharmacology to help the student, pharmacist and doctor: Textbook-directory. Kharkov: Tityl; 2013:444-452.

9. Aslanian MA, Bobrytska LO, Nazarova ES. Pharmacological study of hepatoprotective activity of LAVAFLAM tablets, Pharmacy of the XXI century (VII national congress of pharmacists of Ukraine), Kharkiv; 2016:6.

10. Aslanian MA, Bobrytska LO, Osolodchenko TP. Antibacterial properties of pharmaceutical composition of hepatoprotectors. Annals of Mechnikov Institute. 2016;4:102-106.

11. Aslanyan MA, Bobritskaya LA, Nazarova ES, Mirnaya TA, Zborovskaya TV. Development and Validation of a Gas Chromatography Method for Quantitative Determination of Lavendar Oil in Lavaflam Preparation. Pharm Chem J. 2016;50:47-51.

12. Mashkovskij MD. Lekarstvennye sredstva: Posobie dlja vrachej Moscow; Novaja volna; 2000:500-509.

13. Popova NV, Litvinenko VI, The medicinal plants of world flora. Kharkov; 2008:510

14. Litvinenko VI, Popova NV, Volkovitch OA. Cmins: botanical description, chemical composition, application. Pharmacom. 2001:9-15.

15. Sawilska A, Mielcarek S. The content of flavonoids and polyphenolic acids in inflorescences of Sandy Everlasting [Helichrysum arenarium (L.) Moench] from natural stands and plantations. Herba Pol. 2009;55:118-126.

16. Aslanian MA, Bobrytskaya LA, Nazarova ES, Popova NV, Zborovskaya TV. The development of quality control methods of tablets LAVAFLAM. Management, Economy and Quality Assurance in Pharmacy. 2015;5:9-14.
17. Cosar G, Cubukcu B. Antibacterial activity of Helichrysum species growing in Turkey. Fitoterapia. 1990;61:161-164.

18. Rios JL, Recio MC, Villar A. Isolation and identification of the antibacterial compounds from Helichrysum stoechas. J Ethnopharmacol. 1991;33:5155.

19. Kaij-a-Kamb M, Amoros M, Girre L. Search for new antiviral agents of plant origin. Pharm Acta Helv. 1992;67:130-147.

20. Albayrak S, Aksoy A, Sağdıç O, Hamzaoğlu E. Compositions, antioxidant and antimicrobial activities of Helichrysum (Asteraceae) species collected from Turkey. Food Chem. 2010;119:114-122.

21. Selçuk SS, Birteksöz AS. Flavonoids of Helichrysum chasmolycicum and its antioxidant and antimicrobial activities. S Afr J Bot. 2011;77:170174.

22. European Pharmacopoeia (8th ed). 8.0, Strasbourg: European Department for Quality of Medicines; 2014:1291-1292.

23. Prusinowska R, Smigielski KB. Composition, Biological Properties and Therapeutic Effects of Lavender (Lavandula angustifolia L). Herba Pol. 2014;60:56-66.

24. State Pharmacopoeia of Ukraine, State Enterprise Research Center expert pharmacopoeia, (1st ed). Kharkiv; RIREG; 2001:151-167.

25. Li Q, Rudolph V, Weigl B, Earl A. Interparticle van der Waals force in powder flowability and compactibility. Int J Pharm. 2004;280:77-93.

26. Etti CJ, Yusof YA, Chin NL, Tahir SM. Flowability Properties of Labisia Pumila Herbal Powder. Agriculture and Agricultural Science Procedia. 2014;2:120-127.

27. Buschmann HJ, Schollmeyer E. Applications of cyclodextrins in cosmetic products: A review. J Cosmet Sci. 2002;53:185-191.

28. Challa R, Ahuja A, Ali J, Khar RK. Cyclodextrins in drug delivery: An updated review. AAPS PharmSciTech. 2005;6:329-357.

29. George SJ, Vasudevan DT. Studies on the Preparation, Characterization, and Solubility of 2-HP- $\beta$-Cyclodextrin-Meclizine $\mathrm{HCl}$ Inclusion Complexes. J Young Pharm. 2012;4:220-227.

30. Georgievskiy VP, Konev FA. Technology and standardization of drugs. Kharkov; Rireg; 1996:539-602.

31. Rowe RC, Sheskey PJ, Cook WG, Quinn ME. Handbook of Pharmaceutical excipients, (7th ed). London; Pharmaceutical Press; 2012:1064. 